\title{
Diffusion pathway of mobile ions and crystal structure of ionic and mixed conductors - A brief review
}

\author{
Masatomo YASHIMA ${ }^{\dagger}$ \\ Department of Materials Science and Engineering, Interdisciplinary Graduate School of Science and Engineering, Tokyo Institute of \\ Technology, Nagatsuta-cho 4259-J2-61, Midori-ku, Yokohama-shi, Kanagawa 226-8502
}

A brief review on the field of Solid State Ionics, including the diffusion pathway of mobile ions, crystal structure and materials, is presented. In the fluorite-structured ionic conductors such as ceria solid solution $\mathrm{Ce}_{0.93} \mathrm{Y}_{0.07} \mathrm{O}_{1.96}$, bismuth oxide solid solution $\delta$ - $\mathrm{Bi}_{1.4} \mathrm{Yb}_{0.6} \mathrm{O}_{3}$ and copper iodide $\mathrm{CuI}$, a similar curved diffusion pathway along the $<100>$ directions is observed. In the ionic and mixed conductors with the cubic $\mathrm{ABO}_{3}$ perovskite-type structure such as lanthanum gallate and lanthanum cobaltite solid solutions, the mobile ions diffuse along a curved line keeping the interatomic distance between the $B$ cation and $\mathrm{O}^{2-}$ anion to some degree. The structure and diffusion path of double-perovskite-type $\mathrm{La}_{0.64} \mathrm{Ti}_{0.92} \mathrm{Nb}_{0.08} \mathrm{O}_{2.99}, \mathrm{~K}_{2} \mathrm{NiF}_{4}-\mathrm{type}$ $\left(\operatorname{Pr}_{0.9} \mathrm{La}_{0.1}\right)_{2}\left(\mathrm{Ni}_{0.74} \mathrm{Cu}_{0.21} \mathrm{Ga}_{0.05}\right) \mathrm{O}_{4+\delta}$, and apatite-type $\mathrm{La}_{9.69}\left(\mathrm{Si}_{5.70} \mathrm{Mg}_{0.30}\right) \mathrm{O}_{26.24}$ are described. The diffusion paths of $\mathrm{Li}^{+}$ions in $\mathrm{La}_{0.62} \mathrm{Li}_{0.16} \mathrm{TiO}_{3}$ and $\mathrm{Li}_{0.6} \mathrm{FePO}_{4}$ are two- and one-dimensional, respectively.

(๑2009 The Ceramic Society of Japan. All rights reserved.

Key-words : Neutron powder diffraction, Crystal structure analysis, Maximum-entropy method, lonic conductor, Fluorite-type oxide, Perovskite-type oxide, Apatite-type oxide, Lithium ion conductor

[Received July 1, 2009]

\section{Introduction}

Solid materials with high ionic conductivity have attracted considerable attention owing to their many applications in solid oxide fuel cells (SOFCs), batteries, catalysts, gas sensors and oxygen separation membrane. In an ionic conductor, the mobile ions such as $\mathrm{O}^{2-}, \mathrm{Li}^{+}, \mathrm{Cu}^{+}, \mathrm{Ag}^{+}, \mathrm{F}^{-}, \mathrm{K}^{+}$and $\mathrm{H}^{+}$migrate in the direction of the applied electric field. In an ionic-electronic mixed conductor, not only the mobile ions but also the electrons or electron-holes contribute to the electrical conductivity. A fundamental understanding of the nature of the superionic state has provided one of the major challenges in the field of condensed matter science. The ionic conductivity in ionic and mixed conductors strongly depends on the crystal structure. Therefore the crystal structures of solid materials with high ionic conductivity have extensively been studied. ${ }^{1), 2)}$ Geometric information of the ionic conduction and diffusion is a key to understand the conduction mechanism. ${ }^{2)}$ But, the diffusion pathway of mobile ions in many ionic and mixed conductors was not known sufficiently. The problems in the literature and our strategy to solve them can be summarized as follows.

(1) There exists a lack of crystallographic information at high temperatures. The ionic conductivity of ionic and mixed conductors is high and electrochemical devices operate efficiently at high temperatures. Ionic conduction occurs through the diffusion of mobile ions; thus, it is vital to study the diffusion paths of the mobile ions in the crystal structures of ionic and mixed conductors at high temperatures. We have devised and fabricated new furnaces which enable in situ

Corresponding author: M. Yashima; E-mail: yashima@materia. titech.ac.jp measurements of quality neutron and high-angular-resolution synchrotron powder diffraction data up to $1830 \mathrm{~K}$ in air. ${ }^{3)-6)}$

(2) Many previous works have utilized the split-atom model to express the spatial distribution of mobile ions in the ionic and mixed conductors. But, the split-atom model is not sufficient to describe the continuous and complicated spatial distribution of mobile ions (Fig. 1). Nuclear/electron density analysis from the Bragg intensity can describe the continuous and complicated spatial distribution of the mobile ions (Fig. $1(b))^{2)}$

(3) Some previous works have utilized difference Fourier synthesis and probability density function techniques to deduce the nuclear/electron density distributions; however, these methods might encounter problems related to termination

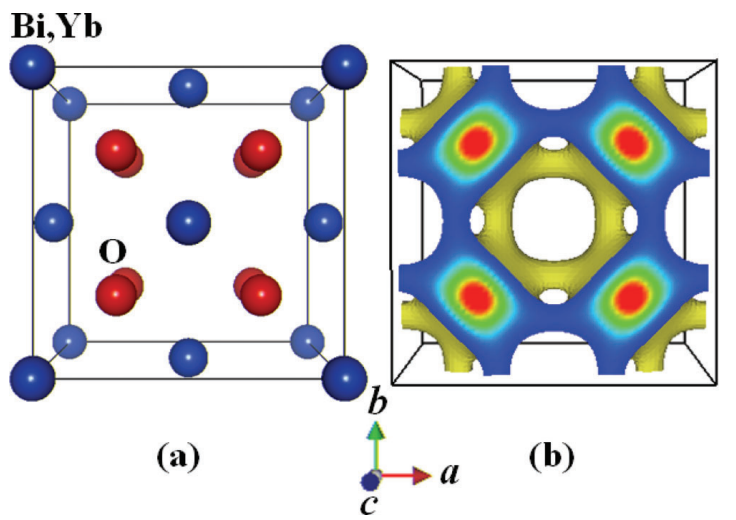

Fig. 1. (Color online). (a) Crystal structure and (b) the isosurface of nuclear-density distribution at $0.1 \mathrm{fm} \AA^{-3}(0.70 \leq z \leq 0.80)$ for $\delta$ $\mathrm{Bi}_{1.4} \mathrm{Yb}_{0.6} \mathrm{O}_{3}$ at $738^{\circ} \mathrm{C}^{10)}$ 
effects and are also model-dependent. To overcome the termination effects, we have applied the maximum-entropy method (MEM) and MEM-based pattern fitting (MPF) to the nuclear/electron density analysis. ${ }^{2)}$ It is known that a precise nuclear/electron density distribution is obtained by the MEM analysis of neutron/X-ray powder diffraction data. ${ }^{2,7), 8}$ The simple structure model utilized in the Rietveld analysis could influence the results of the MEM analysis. Thus, to reduce the bias, it is beneficial to use the MPF technique. ${ }^{2), 8)}$

In the present review paper, the diffusion pathway of mobile ions and crystal structure of the materials with high ionic conductivity, are presented. The materials, mobile ion species, crystal structure and diffusion pathway of mobile ions are summarized in Table 1. The present paper will show that the diffusion pathway of mobile ions is strongly dependent on the crystal structure.

\section{Fluorite-type structured ionic conductors}

Fluorite-structured materials such as bismuth oxide and its solid solution, ceria solid solution, zirconia solid solution, and copper iodide $\mathrm{CuI}$ exhibit high ionic conductivity. Some of these materials are used or candidates for the electrolytes and cathodes of SOFCs, gas sensors and catalysts. The fluorite-type structure is simple: In the fluorite-structured $A X_{2-\delta}$ compound, the $A$ and $X$ atoms are located at $4 a(0,0,0)$ and $8 c(1 / 4,1 / 4,1 / 4)$ sites, respectively. Here the $\delta$ denotes the concentration of oxygen deficiency. For example, in case of $\mathrm{Bi}_{1.4} \mathrm{Yb}_{0.6} \mathrm{O}_{3}, A, X$ and $\delta$ are $\mathrm{Bi}_{0.7} \mathrm{Yb}_{0.3}, \mathrm{O}$ and 0.5 , respectively (Fig. 1(a)). The crystal structure and ionic conduction of these fluorite-structured materials have extensively been studied for many years. However, the diffusion path of mobile ions has been examined insufficiently. We investigated the crystal structure and diffusion path of bismuth oxide $\left(778^{\circ} \mathrm{C}\right){ }^{9)}$ bismuth oxide solid solution $\mathrm{Bi}_{1.4} \mathrm{Yb}_{0.6} \mathrm{O}_{3}$ $\left(738^{\circ} \mathrm{C}\right),{ }^{10)}$ ceria (room temperature to $\left.1497^{\circ} \mathrm{C}\right),{ }^{11), 12)}$ ceria solid solution $\mathrm{Ce}_{0.93} \mathrm{Y}_{0.07} \mathrm{O}_{1.96}\left(1434^{\circ} \mathrm{C}\right),{ }^{13)}$ yttrium tantalum oxide $\mathrm{Y}_{0.785} \mathrm{Ta}_{0.215} \mathrm{O}_{1.715}\left(535^{\circ} \mathrm{C}\right),{ }^{14)}$ and copper iodide $\left.\mathrm{CuI}\left(487^{\circ} \mathrm{C}\right) .{ }^{15}\right)$ $\mathrm{Bi}_{1.4} \mathrm{Yb}_{0.6} \mathrm{O}_{3}, \mathrm{Ce}_{0.93} \mathrm{Y}_{0.07} \mathrm{O}_{1.96}, \mathrm{Y}_{0.785} \mathrm{Ta}_{0.215} \mathrm{O}_{1.715}$ and $\mathrm{CuI}$ exhibit a similar diffusion pathway of mobile ions: The diffusion path is along the $<100>$ directions. The diffusional pathways form a three-dimensional network across unit cells. Figure 1(b) shows the diffusion pathways of mobile oxide ions in $\mathrm{Bi}_{1.4} \mathrm{Yb}_{0.6} \mathrm{O}_{3}$ at $738^{\circ} \mathrm{C}^{10)}$ The pathway is not straight but exhibits an arc shape.

Table 1. Chemical Composition, Mobile Ion Species, Crystal Structure and Diffusion Pathways of Some Ionic and Mixed Conductors

\begin{tabular}{|c|c|c|c|c|}
\hline Materials & $\begin{array}{l}\text { Mobile ion } \\
\text { species }\end{array}$ & $\begin{array}{l}\text { Crystal structure, Crystal } \\
\text { system, Space group }\end{array}$ & $\begin{array}{l}\text { Diffusion pathway of mobile ions, } \\
\text { its dimensionality and figures }\end{array}$ & Ref. \\
\hline $\begin{array}{c}\text { Ceria solid solution } \mathrm{Ce}_{0.93} \mathrm{Y}_{0.07} \mathrm{O}_{1.96} \\
\text { Bismuth oxide solid solution } \\
\delta \text { - } \mathrm{Bi}_{1.4} \mathrm{Yb}_{0.6} \mathrm{O}_{3} \\
\text { Yttrium tantalum oxide } \\
\mathrm{Y}_{0.785} \mathrm{Ta}_{0.215} \mathrm{O}_{1.715}\end{array}$ & $\mathrm{O}^{2-}$ & $\begin{array}{l}\text { Fluorite-type structure } \\
\quad \text { Cubic } F m \overline{3} m\end{array}$ & $\begin{array}{l}\text { Diffusion along the }<100>\text { direc- } \\
\text { tions (Three dimensional network, } \\
\text { Fig. 1) }\end{array}$ & 10 \\
\hline$\alpha-\mathrm{CuI}$ & $\mathrm{Cu}^{+}$ & $\begin{array}{l}\text { Fluorite-type structure } \\
\quad \text { Cubic } F m \overline{3} m\end{array}$ & $\begin{array}{l}\text { Diffusion along the }<100>\text { direc- } \\
\text { tions (Three dimensional network) }\end{array}$ & 15 \\
\hline $\begin{array}{c}\left(\mathrm{La}_{0.8} \mathrm{Sr}_{0.2}\right)\left(\mathrm{Ga}_{0.8} \mathrm{Mg}_{0.15} \mathrm{Co}_{0.05}\right) \mathrm{O}_{3-\delta} \\
\mathrm{La}_{0.6} \mathrm{Sr}_{0.4} \mathrm{CoO}_{3-\delta} \\
\mathrm{La}_{0.6} \mathrm{Sr}_{0.4} \mathrm{Co}_{0.8} \mathrm{Fe}_{0.2} \mathrm{O}_{3-\delta}\end{array}$ & $\mathrm{O}^{2-}$ & $\begin{array}{l}\text { Perovskite-type structure } \\
\text { Cubic } P m \overline{3} m \\
\text { (Trigonal } R \overline{3} c \text { at room } \\
\text { temperature) }\end{array}$ & $\begin{array}{l}\text { Diffusion path with an arc shape } \\
\text { along the } \mathrm{O}-\mathrm{O} \text { edge of the } B \mathrm{O}_{6-\delta} \\
\text { octahedron where the paths are } \\
\text { along }<100>\text { near the stable posi- } \\
\text { tion and along }<110>\text { near the cen- } \\
\text { ter of the path. (Three dimensional } \\
\text { network) (Fig. 2(b)) }\end{array}$ & $\begin{array}{l}16 \\
18 \\
19\end{array}$ \\
\hline $\mathrm{La}_{0.64} \mathrm{Ti}_{0.92} \mathrm{Nb}_{0.08} \mathrm{O}_{2.99}$ & $\mathrm{O}^{2-}$ & $\begin{array}{c}\text { Double perovskite-type } \\
\text { structure, Tetragonal } \\
\text { P4/mmm (Orthorhombic } \\
\text { Cmmm at room temperature) }\end{array}$ & $\begin{array}{l}\text { Diffusion path with an arc shape } \\
\text { along the } \mathrm{O}-\mathrm{O} \text { edge of the } B \mathrm{O}_{6-\delta} \\
\text { octahedron where the paths are } \\
\text { along }<100>\text { near the stable posi- } \\
\text { tion and along }<110>\text { near the cen- } \\
\text { ter of the path. (Two dimensional } \\
\text { network) (Fig. 2(d)) }\end{array}$ & 20 \\
\hline$\left(\mathrm{Pr}_{0.9} \mathrm{La}_{0.1}\right)_{2}\left(\mathrm{Ni}_{0.74} \mathrm{Cu}_{0.21} \mathrm{Ga}_{0.05}\right) \mathrm{O}_{4+\delta}$ & $\mathrm{O}^{2-}$ & $\begin{array}{c}\text { Tetragonal } \mathrm{K}_{2} \mathrm{NiF}_{4} \text {-type } \\
\text { structure, Tetragonal } \mathrm{I} / \mathrm{mmm}\end{array}$ & $\begin{array}{l}\text { Diffusion path with an arc shape } \\
\text { through the } \mathrm{O} 2 \text { and interstitial O3 } \\
\text { atoms (Two-dimensional network) } \\
\text { (Fig. 2(f)) }\end{array}$ & 21 \\
\hline $\mathrm{La}_{9.69}\left(\mathrm{Si}_{5.70} \mathrm{Mg}_{0.30}\right) \mathrm{O}_{26.24}$ & $\mathrm{O}^{2-}$ & $\begin{array}{l}\text { Apatite-type structure } \\
\text { Hexagonal } P 6_{3} / m\end{array}$ & $\begin{array}{l}\text { (1) Diffusion path along the } c \text { axis } \\
\text { (-O4-O4-O4- path, one dimen- } \\
\text { sional path). (2) Another path } \\
\text { along the -O4-O5-O3- atomic } \\
\text { sites (two dimensional) (Fig. 3) }\end{array}$ & 27 \\
\hline $\mathrm{La}_{0.62} \mathrm{Li}_{0.16} \mathrm{TiO}_{3}$ & $\mathrm{Li}^{+}$ & $\begin{array}{c}\text { Orthorhombic } \\
\text { perovskite-related structure } \\
\text { Orthorhombic } \mathrm{Cmmm}\end{array}$ & $\begin{array}{l}\text { Li cations on the La-deficient layer } \\
\text { at } z=1 / 2 \text { diffuse along the }<110> \\
\text { directions (two dimensional) } \\
\text { (Fig. 4) }\end{array}$ & 28 \\
\hline $\mathrm{Li}_{0.6} \mathrm{FePO}_{4}$ & $\mathrm{Li}^{+}$ & $\begin{array}{c}\text { Olivine phase } \\
\text { Orthorhombic Pnma }\end{array}$ & $\begin{array}{l}\text { Curved one-dimensional path of } \mathrm{Li} \\
\text { cation along the }<010>\text { direction }\end{array}$ & 29 \\
\hline
\end{tabular}


Such arc shape in diffusion pathways is also observed in an oxide-ion conductor $\mathrm{Ce}_{0.93} \mathrm{Y}_{0.07} \mathrm{O}_{1.96}{ }^{13)}$ and a copper-cation conductor CuI. ${ }^{15)}$ The diffusion path along the $<100>$ directions would be a common feature of the fluorite-type ionic and mixed conductors $A X_{2-\delta}$, regardless of atomic species $A$ and $X$. The diffusion pathway of the mobile ions would be responsible for the fast ion conduction of these materials.

\section{Ionic and mixed conductors with the perovskite- type and related structures}

Many perovskite-type $\mathrm{ABO}_{3}$ oxides and perovskite related materials exhibit high oxide-ion conductivity and have a wide variety of crystal structures. In this section we describe the diffusion path of mobile oxide ions in the solid oxides with cubic perovskite-type structure $\left(\left(\mathrm{La}_{0.8} \mathrm{Sr}_{0.2}\right)\left(\mathrm{Ga}_{0.8} \mathrm{Mg}_{0.15} \mathrm{Co}_{0.05}\right) \mathrm{O}_{3-\delta},{ }^{16), 17}\right)$ $\mathrm{La}_{0.6} \mathrm{Sr}_{0.4} \mathrm{CoO}_{3-\delta},{ }^{18)} \mathrm{La}_{0.6} \mathrm{Sr}_{0.4} \mathrm{Co}_{0.8} \mathrm{Fe}_{0.2} \mathrm{O}_{3-\delta}{ }^{19)}$ ), double perovskitetype structure $\left(\mathrm{La}_{0.64} \mathrm{Ti}_{0.92} \mathrm{Nb}_{0.08} \mathrm{O}_{2.99}{ }^{20)}\right)$ and $\mathrm{K}_{2} \mathrm{NiF}_{4}$-type structure $\left(\left(\mathrm{Pr}_{0.9} \mathrm{La}_{0.1}\right)_{2}\left(\mathrm{Ni}_{0.74} \mathrm{Cu}_{0.21} \mathrm{Ga}_{0.05}\right) \mathrm{O}_{4+\delta}{ }^{21)}\right)$.

After the discovery of the lanthanum gallate-based phases, ${ }^{22)}$ the crystal structures of the materials have been the subject of a number of investigations. Neutron diffraction experiments of $\left(\mathrm{La}_{0.8} \mathrm{Sr}_{0.2}\right)\left(\mathrm{Ga}_{0.8} \mathrm{Mg}_{0.15} \mathrm{Co}_{0.05}\right) \mathrm{O}_{3-\delta}$ (LSGMC) at $1392^{\circ} \mathrm{C}$ indicated that the LSGMC has the cubic $P m \overline{3} m$ perovskite-type structure. ${ }^{16)}$ Refined atomic displacement parameters of oxygen atom in cubic LSGMC exhibits a large anisotropy: $U_{11}=0.0292(13)$ $\AA^{2} ; U_{22}=U_{33}=0.0935(13) \AA^{2} ; U_{12}=U_{13}=U_{23}=0.0 \AA^{2}$ (Fig. 2(a)). ${ }^{16)}$ The nuclear density distribution of the cubic $P m \overline{3} m$ LSGMC indicates that oxide ions exhibit a large anisotropic distribution, corresponding to the large anisotropy in the atomic displacement parameters (Fig. 2(b)). ${ }^{16)}$ The diffusion path of oxide ions in the cubic LSGMC does not follow the edge of the $B \mathrm{O}_{6-\delta}\left[=\left(\mathrm{Ga}_{0.8} \mathrm{Mg}_{0.15} \mathrm{Co}_{0.05}\right) \mathrm{O}_{5.6}\right]$ octahedron (Straight lines $\mathrm{O}-$
$\mathrm{Oa}, \mathrm{O}-\mathrm{Ob}$ and $\mathrm{O}-\mathrm{Oc}$ in Fig. 2(a)) but displays an arc shape away from the $B$-site cation (Curves $\mathrm{O}-\mathrm{Oa}, \mathrm{O}-\mathrm{Ob}$ and $\mathrm{O}-\mathrm{Oc}$ in Fig. 2(b)). Similar anisotropic thermal motion of oxygen atoms was observed in the MEM nuclear density maps of $\mathrm{La}_{0.6} \mathrm{Sr}_{0.4} \mathrm{CoO}_{3-\delta}{ }^{18)}$ and $\mathrm{La}_{0.6} \mathrm{Sr}_{0.4} \mathrm{Co}_{0.8} \mathrm{Fe}_{0.2} \mathrm{O}_{3-\delta}{ }^{19)}$ The diffusion pathways of oxide ions in $\mathrm{La}_{0.6} \mathrm{Sr}_{0.4} \mathrm{CoO}_{3-\delta}{ }^{18)}$ and $\mathrm{La}_{0.6} \mathrm{Sr}_{0.4} \mathrm{Co}_{0.8} \mathrm{Fe}_{0.2} \mathrm{O}_{3-\delta}{ }^{19)}$ were suggested to be curved as well as in LSGMC. The curve feature in the diffusion pathway of oxide ions in cubic perovskite-type $A B \mathrm{O}_{3-\delta}$ ionic and mixed conductors might be common regardless of atomic species $A$ and $B$. This conclusion is consistent with the theoretical calculations ${ }^{23)}$ and probability density function analysis $^{24)}$ in the literature.

Neutron powder diffraction patterns of $\mathrm{La}_{0.64}\left(\mathrm{Ti}_{0.92} \mathrm{Nb}_{0.08}\right) \mathrm{O}_{2.99}$ at $496^{\circ} \mathrm{C}, 1008^{\circ} \mathrm{C}$ and $1358^{\circ} \mathrm{C}$ indicated a double perovskite-type structure with tetragonal $P 4 / \mathrm{mmm}$ space group $\left(a \approx a_{\mathrm{p}} \times b \approx\right.$ $a_{\mathrm{p}} \times c \approx 2 a_{\mathrm{p}}$; the subscript $\mathrm{p}$ denotes a pseudo cubic perovskitetype structure) (Fig. 2(c)). Refined atomic displacement parameters of oxygen $\mathrm{O} 3$ atom exhibit a large anisotropy, which lead to the motion of $\mathrm{O} 3$ atom in the $<100>$ directions. ${ }^{20)}$ The diffusion paths of oxide ions along the $\langle 110\rangle$ directions maintaining a constant distance from the $B$-site cation are observed near the $a b$ planes at $z=1 / 4$ and $3 / 4$ in the double perovskite-structured $\mathrm{La}_{0.64}\left(\mathrm{Ti}_{0.92} \mathrm{Nb}_{0.08}\right) \mathrm{O}_{2.99}$ (Curves O3-O3 in Fig. 2(d)), ${ }^{20)}$ which is similar with that in LSGMC.

Rietveld analysis of the neutron diffraction data of $\left(\mathrm{Pr}_{0.9} \mathrm{La}_{0.1}\right)_{2}\left(\mathrm{Ni}_{0.74} \mathrm{Cu}_{0.21} \mathrm{Ga}_{0.05}\right) \mathrm{O}_{4+\delta}$ at $1016^{\circ} \mathrm{C}$ indicated the $\mathrm{K}_{2} \mathrm{NiF}_{4}$-type structure with tetragonal $I 4 / \mathrm{mmm}$ space group. ${ }^{21)}$ The crystal structure of $\left(\mathrm{Pr}_{0.9} \mathrm{La}_{0.1}\right)_{2}\left(\mathrm{Ni}_{0.74} \mathrm{Cu}_{0.21} \mathrm{Ga}_{0.05}\right) \mathrm{O}_{4+\delta}$ consists of $(\mathrm{Pr}, \mathrm{La})(\mathrm{Ni}, \mathrm{Cu}, \mathrm{Ga}) \mathrm{O}_{3}$ perovskite-type and $(\mathrm{Pr}, \mathrm{La}) \mathrm{O}$ rock-salt-type units (Fig. 2(e)). Refined occupancy factors indicate the excess oxygen of $\delta=0.0154(3)$ in $\left(\mathrm{Pr}_{0.9} \mathrm{La}_{0.1}\right)_{2}\left(\mathrm{Ni}_{0.74} \mathrm{Cu}_{0.21} \mathrm{Ga}_{0.05}\right) \mathrm{O}_{4+\delta}$, which is ascribed to the interstitial $\mathrm{O} 3$ atom in the $(\mathrm{Pr}, \mathrm{La}) \mathrm{O}$ rock- (a)

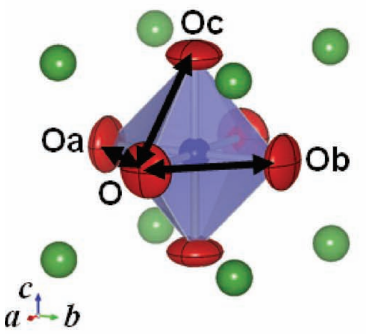

(b)

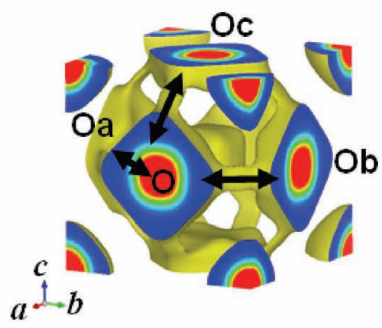

(c)

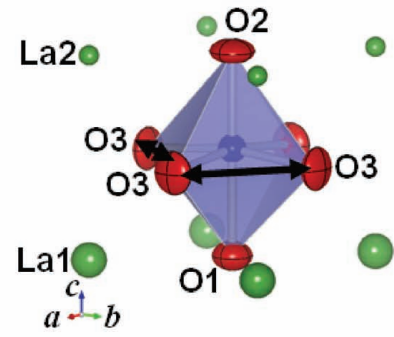

(d)

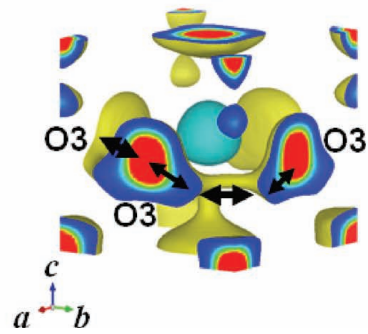

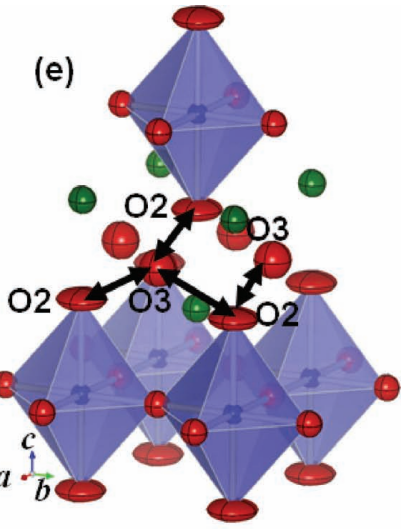

(f)

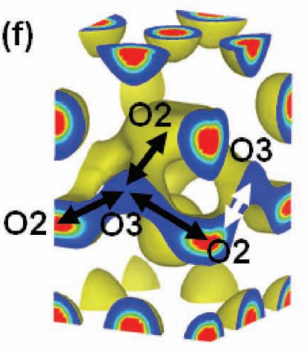

Fig. 2. (Color online). Crystal structure (a) and isosurface of nuclear density (b) of $\left(\mathrm{La}_{0.8} \mathrm{Sr}_{0.2}\right)\left(\mathrm{Ga}_{0.8} \mathrm{Mg}_{0.15} \mathrm{Co}_{0.05}\right) \mathrm{O}_{3-} \delta$ at $1392^{\circ} \mathrm{C}$. Crystal structure (c) and isosurface of nuclear density (d) of $\mathrm{La}_{0.64}\left(\mathrm{Ti}_{0.92} \mathrm{Nb}_{0.08}\right) \mathrm{O}_{2.99}$ at $1358^{\circ} \mathrm{C}(0 \leq z \leq 1 / 2)$. Crystal structure (e) and isosurface of nuclear density (f) of $\left(\mathrm{Pr}_{0.9} \mathrm{La}_{0.1}\right)_{2}\left(\mathrm{Ni}_{0.74} \mathrm{Cu}_{0.21} \mathrm{Ga}_{0.05}\right) \mathrm{O}_{4+\delta}$ at $1016^{\circ} \mathrm{C}(0 \leq z \leq 1 / 2)$. Details of the crystallographic parameters of $\left(\mathrm{La}_{0.8} \mathrm{Sr}_{0.2}\right)\left(\mathrm{Ga}_{0.8} \mathrm{Mg}_{0.15} \mathrm{Co}_{0.05}\right) \mathrm{O}_{3-\delta}, \mathrm{La}_{0.64}\left(\mathrm{Ti}_{0.92} \mathrm{Nb}_{0.08}\right) \mathrm{O}_{2.99}$ and $\left(\mathrm{Pr}_{0.9} \mathrm{La}_{0.1}\right)_{2}\left(\mathrm{Ni}_{0.74} \mathrm{Cu}_{0.21} \mathrm{Ga}_{0.05}\right) \mathrm{O}_{4+\delta}$ are described in $\mathrm{Refs}_{\text {. }} 16,20$ and 21 , respectively. 
salt-type unit $((x, 0, z)$ where $x=0.666(19)$ and $z=0.223(9)$; Fig. $2(\mathrm{e}))$. The oxygen atom at the $\mathrm{O} 2$ site $(4 e ;(0,0, z)$; $z=0.1752(4))$ exhibits highly anisotropic thermal motion $\left(U_{11}=\right.$ $U_{22}=0.115(3) \AA^{2}$ and $U_{33}=0.021(3) \AA^{2}$ ), which lead to the motion of oxygen $\mathrm{O} 2$ atoms along the $<100>$ directions. The oxide ions diffuse through the $\mathrm{O} 2$ and interstitial $\mathrm{O} 3$ sites $(\mathrm{O} 2-$ $\mathrm{O} 3-\mathrm{O} 2$ path in Fig. 2(f)). ${ }^{21)}$ It is interesting that the oxide ions do not diffuse along the $\mathrm{O}-\mathrm{O}$ edge of $(\mathrm{Ni}, \mathrm{Cu}, \mathrm{Ga}) \mathrm{O}_{6}$ octahedron, but through the interstitial $\mathrm{O} 3$ atomic site.

The cubic LSGMC perovskite has a three-dimensional network of oxide-ion diffusion paths (Fig. 2(b)), whereas the double perovskite-structured $\mathrm{La}_{0.64}\left(\mathrm{Ti}_{0.92} \mathrm{Nb}_{0.08}\right) \mathrm{O}_{2.99}$ and $\mathrm{K}_{2} \mathrm{NiF}_{4}$-type $\left(\mathrm{Pr}_{0.9} \mathrm{La}_{0.1}\right)_{2}\left(\mathrm{Ni}_{0.74} \mathrm{Cu}_{0.21} \mathrm{Ga}_{0.05}\right) \mathrm{O}_{4+\delta}$ exhibit a two-dimensional network of diffusion paths on the $a b$ planes at around $z=1 / 4$ and 3/4 (Figs. 2(d) and 2(f)). The two-dimensional network of diffusional paths is ascribed to the layers of different structure units in the crystal structure.

\section{Apatite-type oxide-ion conductor}

After the discovery of the apatite-type ionic conductor by Nakayama et al., ${ }^{25)}$ this material has extensively been studied. But, the diffusion pathway of oxide ions in the apatite-type ionic conductors was not established. We chose the chemical composition $\mathrm{La} 9.69\left(\mathrm{Si}_{5.70} \mathrm{Mg}_{0.30}\right) \mathrm{O}_{26.24}$, because it exhibits higher ionic conductivity. ${ }^{26)}$ Nuclear density distributions of oxide-ion conductor $\mathrm{La}_{9.69}\left(\mathrm{Si}_{5.70} \mathrm{Mg}_{0.30}\right) \mathrm{O}_{26.24}$ with the apatite-type structure (space group $\mathrm{P6}_{3} / \mathrm{m}$ ) were determined by the whole-pattern fitting approach based on the maximum-entropy method (MEM) using neutron powder diffraction data measured at $1558^{\circ} \mathrm{C}^{27)}$ The Rietveld refinement confirmed that the structure of apatitetype $\mathrm{La}_{9.69}\left(\mathrm{Si}_{5.70} \mathrm{Mg}_{0.30}\right) \mathrm{O}_{26.24}$ consists of $(\mathrm{Si}, \mathrm{Mg}) \mathrm{O}_{4}$ tetrahedra, $\mathrm{La}$ and oxygen atoms, and suggested an interstitial oxygen (O5) atom site $(12 i ; x, y, z ; x \approx 0, y \approx 0.22, z \approx 0.65)$ at the periphery of the hexagonal axis (Fig. 3). ${ }^{27)}$ The oxide ions located at $2 a$ $(\mathrm{O} 4)$ and $12 i(\mathrm{O} 3)$ sites are largely distributed parallel and perpendicular to the $c$ axis, respectively. The nuclear density derived from the MEM analysis revealed that the $\mathrm{O} 4$ oxide ions located at $2 a$ site $(0,0,1 / 4)$ diffuse to the nearest-neighbor $2 a$ sites along the [001] direction (-O4-O4- in Fig. 3). ${ }^{27)}$ This [001] diffusion path is linearly linked with that of a neighboring unit cell, which forms a long-range, one-dimensional oxide-ion diffusion pathway extending along the $c$ axis of the hexagonal $P 6_{3} / m$ framework. On the other hand, the oxide ions O3 (12i site) are largely distributed perpendicular to the $c$ axis. The nuclear density of the $\mathrm{O} 3$ ion is connected with that of the equivalent $\mathrm{O} 3$ of the same tetrahedron through the interstitial $\mathrm{O} 5$ ion, indicating migration of the oxide ions along a curved line connecting O3-O5-O3 atoms (Fig. 3). This migration path is non-linear (U-shaped) and perpendicular to the $c$ axis. The densities of the two kinds of oxide ions (O4 and $\mathrm{O} 3$ ) migrating parallel and perpendicular to the $c$ axis, respectively, connected with each other through the densities of interstitial oxide ion (O5). The results suggest that the $\mathrm{O} 4$ ion migrates via vacancy mechanism with a direct linear path along $c$ axis, while the $\mathrm{O} 3$ ion migration perpendicular to the $c$ axis involves an interstitial mechanism.

\section{Lithium-cation conductors}

Solid materials with a high lithium-ion conductivity are important for the development of all-solid-state lithium batteries. The discovery of the lithium-doped lanthanum titanate $A B \mathrm{O}_{3}$ perovskite, $\left(A=\mathrm{La}_{2 / 3-x}\right.$ and $\left.B=\mathrm{Ti}\right) \mathrm{La}_{2 / 3-} \mathrm{Li}_{3 x} \mathrm{TiO}_{3}$, has stimulated wide interest because it is the highest bulk $\mathrm{Li}$ cation conducting solid electrolyte. We performed a neutron powder diffraction study of the $\mathrm{La}_{0.62} \mathrm{Li}_{0.16} \mathrm{TiO}_{3}$ perovskite that determined the crystal structure (space group: Cmmm) and diffusion path of lithium cations at room temperature. ${ }^{28)}$ At $77 \mathrm{~K}$, the Li cations are located at the $2 c$ site of the Cmmm space group on the La deficient layer at $z=1 / 2$, while at room temperature, they are spread over a wide area and migrate following the $2 c-4 f-2 c$ or $4 f-2 d-4 f$ tie line along

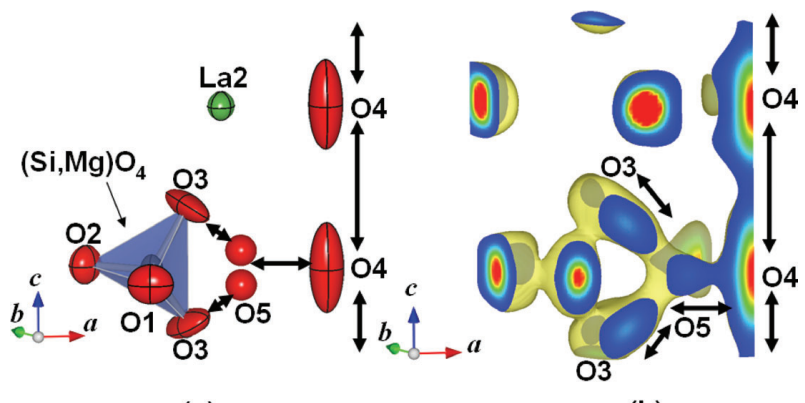

(a)

Fig. 3. (Color online). Crystal structure (a) and isosurface of nuclear density (b) of $\mathrm{La}_{9.69}\left(\mathrm{Si}_{5.70} \mathrm{Mg}_{0.30}\right) \mathrm{O}_{26.24}$ at $1558^{\circ} \mathrm{C}(1 / 2 \leq x \leq 1,0 \leq y \leq 0.2)$. Details of the crystallographic parameters are described in Ref. 27.

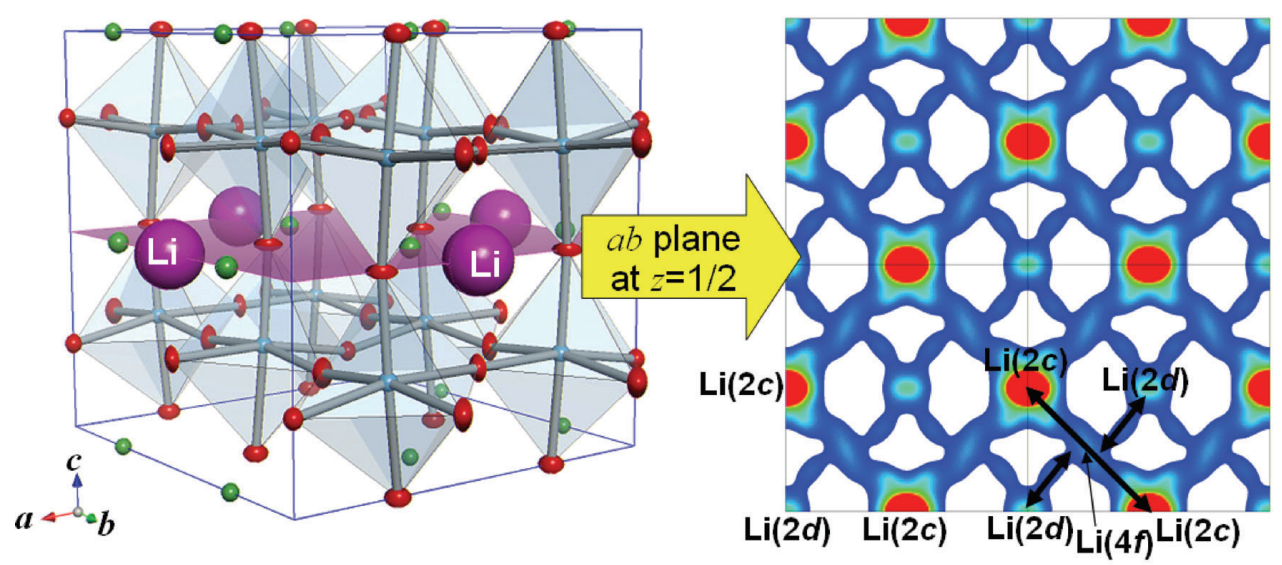

(a)

(b)

Fig. 4. (Color online). Crystal structure (a) and nuclear density on the $a b$ plane at $z=1 / 2$ (b) of $\mathrm{La}_{0.62} \mathrm{Li}_{0.16} \mathrm{TiO}_{3.0}$ at room temperature. Details of the crystallographic parameters are described in Ref. 28. 
the $<110>$ directions on the La deficient layer at $z=1 / 2$ (Fig. 4). The probability density of $\mathrm{Li}$ cations has a minimum between the $2 c$ and $4 f$ or between the $4 f$ and $2 d$ positions on the diffusion path in contrast to the previous reports where the bottleneck has been thought to be located at the $2 c, 2 d$ and $4 f$ positions.

We also studied the diffusion pathway of $\mathrm{Li}$ cations in $\mathrm{Li}_{0.6} \mathrm{FePO}_{4}$ by the Rietveld, MEM and MPF analysis of neutron diffraction data. ${ }^{29)}$ It was found that the $\mathrm{Li}$ cations exhibit a curved one-dimensional diffusional pathways along the $<010>$ directions.

\section{Concluding remarks}

We have briefly reviewed our recent works on the diffusion pathway of mobile ions, crystal structures and materials. The results are summarized in Table 1. In the fluorite-structured ionic conductors such as ceria solid solution $\mathrm{Ce}_{0.93} \mathrm{Y}_{0.07} \mathrm{O}_{1.96}$, bismuth oxide solid solution $\delta$ - $\mathrm{Bi}_{1.4} \mathrm{Yb}_{0.6} \mathrm{O}_{3}$ and copper iodide $\alpha$-CuI, a similar curved diffusion pathway along the $<100>$ directions is observed. In the ionic and mixed conductors with the cubic $\mathrm{ABO}_{3}$ perovskite-type structure such as lanthanum gallate and lanthanum cobaltite solid solutions, the mobile ions diffuse along a curved line keeping the interatomic distance between the $B$ cation and $\mathrm{O}^{2-}$ anion to some degree. The structures and diffusion paths of double-perovskite-type $\mathrm{La}_{0.64} \mathrm{Ti}_{0.92} \mathrm{Nb}_{0.08} \mathrm{O}_{2.99}$, $\mathrm{K}_{2} \mathrm{NiF}_{4}$-type $\left(\mathrm{Pr}_{0.9} \mathrm{La}_{0.1}\right)_{2}\left(\mathrm{Ni}_{0.74} \mathrm{Cu}_{0.21} \mathrm{Ga}_{0.05}\right) \mathrm{O}_{4+\delta}$, and apatite-type $\mathrm{La9.69}\left(\mathrm{Si}_{5.70} \mathrm{Mg}_{0.30}\right) \mathrm{O}_{26.24}$ have also been described. The diffusion paths of $\mathrm{La}_{0.62} \mathrm{Li}_{0.16} \mathrm{TiO}_{3}$ and $\mathrm{Li}_{0.6} \mathrm{FePO}_{4}$ are two- and one-dimensional, respectively.

Acknowledgments This work was partly supported by the Grantin-Aid for Scientific Research (KAKENHI) (B) of Japan Society for the Promotion of Science (JSPS) (No. 21360318). The author would like to express thanks to all the coauthors, collaborators and students in the research works described in the original papers. The diffraction data were taken by the HERMES and HRPD neutron diffractometers, and by the synchrotron powder diffractometers at the beam lines BL02B2 of SPring- 8 and BL- $4 \mathrm{~B}_{2}$ of the Photon Factory. Figures $1-4$ were drawn with VESTA ${ }^{30)}$ and VENUS. ${ }^{8)}$

\section{References}

1) S. Hull, Rep. Prog. Phys., 67 1233-1314 (2004).

2) M. Yashima, Solid State Ionics, 179, 797-803 (2008).

3) M. Yashima, J. Am. Ceram. Soc., 85, 2925-2930 (2002).

4) M. Yashima and M. Tanaka, J. Appl. Cryst., 37, 786-790 (2004).

5) M. Yashima, M. Tanaka, K. Oh-uchi and T. Ida, J. Appl. Cryst., 38, 854-855 (2005).
6) M. Yashima, K. Oh-uchi, M. Tanaka and T. Ida, J. Am. Ceram. Soc., 89, 1395-1399 (2006).

7) M. Sakata, T. Uno, M. Takata and C. H. Howard, J. Appl. Cryst., 26, 159-165 (1993).

8) F. Izumi and R. A. Dilanian, "Recent Research Developments in Physics," Vol. 3, Part II, Transworld Research Network, Trivandrum, p. 699 (2002).

9) M. Yashima and D. Ishimura, Chem. Phys. Lett., 378, 395-399 (2003).

10) M. Yashima and D. Ishimura, Appl. Phys. Lett., 87, 221909 (3 pages) (2005).

11) M. Yashima and S. Kobayashi, Appl. Phys. Lett., 84, 526-528 (2004).

12) M. Yashima, S. Kobayashi and T. Yasui, Solid State Ionics, 177, 211-215 (2006).

13) M. Yashima, S. Kobayashi and T. Yasui, Faraday Discussions, 134, 369-376 (2007).

14) M. Yashima and T. Tsuji, Chem. Mater., 19[14], 3539-3544 (2007).

15) M. Yashima, Q. Xu, A. Yoshiasa and S. Wada, J. Mater. Chem., 16, 4393-4396 (2006).

16) M. Yashima, K. Nomura, H. Kageyama, Y. Miyazaki, N. Chitose and K. Adachi, Chem. Phys. Lett., 380[3-4], 391-396 (2003).

17) M. Yashima, "Perovskite Oxide in Solid Oxide Fuel Cells, Series: Fuel Cells and Hydrogen Energy," Ed. by T. Ishihara, Springer-Verlag Press (2009) pp. 117-145.

18) M. Yashima and T. Tsuji, J. Appl. Cryst., 40, 1166-1168 (2007).

19) M. Yashima and T. Kamioka, Solid State Ionics, 179, 19391943 (2008).

20) R. Ali, M. Yashima and F. Izumi, Chem. Mater., 19, 32603264 (2007).

21) M. Yashima, M. Enoki, T. Wakita, R. Ali, Y. Matsushita, F. Izumi and T. Ishihara, J. Am. Chem. Soc., 139, 2762-2763 (2008).

22) T. Ishihara, H. Matsuda and Y. Takita, J. Am. Chem. Soc., 116, 3801-3803 (1994).

23) M. S. Islam, J. Mater. Chem., 10, 1027-1038 (2000).

24) M. Lerch, H. Boysen and T. Hansen, J. Phys. Chem. Solids, 62, 445-455 (2001).

25) S. Nakayama, H. Aono and Y. Sadaoka, Chem. Lett., 6, 431432 (1995)

26) H. Yoshioka, Chem. Lett., 33, 392-393 (2004).

27) R. Ali, M. Yashima, Y. Matsushita, H. Yoshioka, K. Ohoyama and F. Izumi, Chem. Mater., 20, 5203-5208 (2008).

28) M. Yashima, M. Itoh, Y. Inaguma and Y. Morii, J. Am. Chem. Soc., 127, 3491-3495 (2005).

29) S. Nishimura, G. Kobayashi, K. Ohoyama, R. Kanno, M. Yashima and A. Yamada, Nat. Mater., 7, 707-711 (2008).

30) K. Momma and F. Izumi, J. Appl. Cryst., 41, 653-658 (2008).

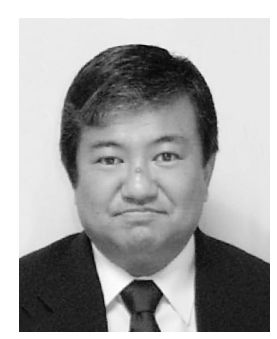

Masatomo Yashima was born in 1963 in Aichi, Japan. He received his B. S. from Tsukuba University in 1986 and obtained his $\mathrm{Ph}$. D. in Materials Science and Engineering from Tokyo Institute of Technology in 1991. He was a research associate of Materials and Structures Laboratory of Tokyo Institute of Technology in 1991-1997. He has been working at Department of Materials Science and Engineering, Interdisciplinary Graduate School of Science and Engineering, Tokyo Institute of Technology as an associate professor (1997- now 2009). His current research interests include crystal structure and electron/nuclear density analysis of ceramic materials such as ionic and mixed conductors and catalysts. 